\title{
Does One Mens Rea Fit All?: Thoughts on Alexander's Unified Conception of Criminal Culpability
}

\author{
Joshua Dressler†
}

Like Sandy Kadish, the man whom we have come together to honor at Boalt Hall, ${ }^{1}$ Larry Alexander is an immensely thoughtful and productive scholar. Alexander's new Essay ${ }^{2}$ is, as usual, provocative. His thesis is that the current tripartite subjective fault system, in which the law distinguishes between the mental states of purpose, knowledge, and recklessness, is unwise and unnecessary. According to Alexander, purpose and knowledge are reducible to recklessness, because all three culpable mental states share the same "basic moral vice of insufficient concern for the interests of others" or, for short, "callousness" or "indifference." Since Alexander would also abandon negligence as a form of criminal culpability, ${ }^{5}$ he apparently favors

Copyright $\odot 2000$ California Law Review, Inc. California Law Review, Incorporated (CLR) is a California nonprofit corporation. CLR and the authors are solely responsible for the content of their publications.

$\dagger \quad$ Professor of Law, McGeorge School of Law, University of the Pacific. A version of these comments was presented at "The Morality of Criminal Law" symposium honoring Sandy Kadish, on October 2, 1999. I thank the participants for their comments during and after the presentation.

1. Sandy Kadish has credited the late Glanville Williams with "rais[ing] the study of the substantive criminal law [in England] to a new plane." Sanford H. Kadish, Fifty Years of Criminal Law: An Opinionated Review, 87 CALIf. L. Rev. 943, 950 (1999). On this side of the Atlantic, nobody deserves our appreciation more than Kadish for his nearly half-century of work in the fields of criminal law scholarship and penal reform. And, of course, his criminal law casebook, CRiminal LAw AND ITS Processes: Cases and Materials, created with the late Monrad Paulsen in 1962 and now coauthored by Stephen Schulhofer, remains the standard by which all criminal law casebooks are measured.

2. See Larry Alexander, Insufficient Concern: A Unified Conception of Criminal Culpability, 88 Calif. L. Rev. 931 (2000).

3. Id. at 931 .

4. Id. at 937.

5. See Larry Alexander, Reconsidering the Relationship Among Voluntary Acts, Strict Liability, and Negligence in Criminal Law, 7 Soc. PHIL. \& PoL'y 84 (1990). In his present essay, Alexander candidly concedes that "most people's intuitions run against me on the issue of whether inadvertent negligence is culpable." Alexander, supra note 2 at 950 . He is correct. I use a version of Alexander's hypothetical yuppie social climbers, Sam and Ruth, in my criminal law casebook, CASES AND MATERIALS ON CRIMINAL LAW 282 (2d ed. 1999), although I rely on an earlier version found in his Social Philosophy and Policy essay. In classes I have taught at Boalt Hall and McGeorge, students have overwhelmingly found the parents culpable. The students believe that the parents were, or should have been, aware of an unjustified risk, albeit perhaps statistically slight, to their infant's welfare when they 
a penal code containing a single culpability term, recklessness, ${ }^{6}$ rather than the countless mens rea terms found in the common law and nonreformed statutory systems, and instead of the Model Penal Code's streamlined fourlevel culpability hierarchy. In the limited space I have to respond, I will touch upon just a few of Alexander's arguments. ${ }^{7}$

I preface my comments with a brief observation. A proponent of a unified conception of criminal culpability can justify this position on at least one of three grounds: (1) purposeful, knowing, and reckless wrongdoers who cause the same harm are equally blameworthy; (2) they are not equally blameworthy, but the differences in culpability are de minimis; and (3) whether or not significant differences in culpability exist, there is no reliable way to draw distinctions, so we are better off with a one-mens-reafits-all system. I read Alexander as accepting the first proposition. Although I have my own reservations about aspects of our current culpability hierarchy system, I am prepared here to defend it against Alexander's attack.

\section{I}

\section{RECKLESSNESS}

The essential feature of Alexander's essay is his conceptualization of the state of mind of recklessness. Alexander focuses on the analytical work of Kenneth Simons, who asserts that the ordinary hierarchy of mental states-wherein purpose is treated as the most culpable state of mind, followed by knowledge, recklessness, and negligence-fails to take into account that there are two distinct and independent categories of mental states: There are culpable states of belief (for example, knowledge) and culpable states of desire (for example, purpose). ${ }^{8}$ Simons contends that the

shifted their attention to the party. As Alexander demonstrates in the present essay, even an extremely small enhanced risk taken for trivial reasons, such as social climbing, can be unjustified.

6. See Alexander, supra note 2, at 946 ("I would make recklessness the only mens rea for criminal liability ....").

7. One of the arguments with which I will not deal in any detail here is the issue of accomplice liability, which Alexander discusses in Part III as one of the so-called "problem cases" for his unified culpability approach. Alexander's purpose in this section is to show that the law can satisfactorily, even desirably, deal with the various doctrines that currently require proof of purpose or intent, such as complicity and inchoate liability, within a unified "recklessness" system. See Alexander, supra note 2, at 944-949. However, even one who believes in a multilevel culpability system-one who rejeets Alexander's thesis here-could still advocate, for example, liability for reckless complicity, as Sandy Kadish recently contemplated in Reckless Complicity, 87 J. CRIM. L. \& CRIMINology 369 (1997), and as Alexander defends here.

I have written elsewhere on the subject of complicity and have proposed reforms of accessory law. See Joshua Dressler, Reassessing the Theoretical Underpinnings of Accomplice Liability: Providing Some New Solutions to an Old Problem, 37 Hastings L.J. 91 (1985); see also Joshua Dressler, The Jurisprudence of Death by Another: Accessories and Capital Punishment, 51 U. Colo. L. Rev. 17 (1979). This is not the place to develop my differences with Alexander (and Kadish) in this regard.

8. See Kenneth W. Simons, Rethinking Mental States, 72 B.U. L. REv. 463 (1992). 
law can usefully devise hierarchies within a category, but not across categories. 9 Simons further suggests that recklessness is itself divisible into two independent states of mind, one involving a belief-state (awareness of a substantial risk) and the other a desire-state (reckless indifference). ${ }^{10}$ Alexander argues that Simons has it wrong, that the state of mind of recklessness (and, for that inatter, purpose and knowledge) always contains both a belief-state and a desire-state. Therefore, Simons's approach is "either unnecessary ... or troubling."

I disagree in certain respects with Alexander's characterization of recklessness. But let me first note the more significant areas of agreement. Alexander is right not to divide recklessness, as Simons does, into separate categories. Instead, he shows that recklessness always involves a beliefstate (awareness of a risk) and a desire-state (the reasons for taking the risk). Also, as Alexander demonstrates, the core of reckless conduct is not the substantiality of risk-taking-_" [e]ven very tiny risk-impositions can be reckless if imposed for insufficient or misanthropic reasons"12 - but its unjustifiability. To determine justifiability, we conduct a criminal law version of the Learned Hand formula for measuring civil negligence ${ }^{13}$ (but add in a requirement of advertence, to which I will turn shortly): We determine the extent of harm risked by the conduct discounted by its likelihood of occurring and weigh that against the actor's motivation for the conduct (the perceived benefits, to the individual or others, accruing from the conduct) discounted by the probability that the risky behavior will satisfy the actor's goals. For Alexander, unjustifiable risk-taking (with advertence) constitutes recklessness, which in turn represents our judgment that the actor has acted callously or with insufficient concern for the rights of others.

In contrast to the Model Penal Code, which textually treats substantiality of risk as an independent element of recklessness, "substantiality" falls below the horizon in Alexander's picture. In iny view, it should not be omitted from the analysis; however, I would revise the Code formula slightly. Some risk-taking is unjustifiable, but only barely so. The scales may tip only ever-so-slightly against certain conduct. The defendant's behavior might be so close to the line that the jury has to wrestle long and

9. See id. at 476 .

10. See id. at 482 .

11. Alexander, supra note 2, at 937 . Alexander does not have his heart in this accusation. He posits the possibility that Simons would punish a person solely for actiug with a culpable character flaw (callousness) rather than on the basis of an occurrent mental state. This position would be troubling, but Alexander finds little in Simons's article to support this interpretation and doubts his own accusation. See id. at 938.

12. Id. at 934.

13. See United States v. Carroll Towing Co., 159 F.2d 169, 173 (2d Cir. 1947) ("[I]n algebraic terms: if the probability be called $\mathrm{P}$; the injury L; and the burden $\mathrm{B}$; liability depends upon whether $\mathrm{B}$ is less than L multiplied by P: i.e., whether B is less than PL.")

14. See Model Penal Code \$ 2.02(2)(c) (1985). 
hard before it determines that it is unjustifiable. Alternatively, the issue might be a "no-brainer"; the gravity and probability of harm risked may so greatly outdistance the perceived benefits of the conduct that we can conclude that the actor's behavior was not simply unjustifiable, but that it was enormously so. It is this latter aspect of recklessness that should constitute the substantiality feature of the recklessness formula. That is, "substantial" should not be read as an adjective modifying "risk," but rather as an adverb modifying "unjustified risk." Criminal recklessness, as I see it, exists when one takes a substantially unjustified—or, if you wish, grossly unjustifiedrisk.

This may be what the Model Penal Code really intends to suggest anyway, in view of the Commentary's observation that "less substantial risks might suffice for liability if there is no pretense of any justification for running the risk." 15 Of course, risk-taking is infinitely greater than it should be if there is no justification for it; it is much the same when there is a pretense of justification, but it is a frivolous one ${ }^{16} \mathrm{My}$ interpretation is also consistent with Code language not quoted by Alexander, namely, that the " $[r] i s k$... be of such a nature and degree that, considering the nature and purpose of the actor's conduct... its disregard involves a gross deviation from the standard of conduct that a law-abiding person would observe in the actor's situation."17 Society should require that the disregard for the rights of others be "gross"-in other words, that the unjustifiability of the risk-taking be substantial-because, of course, this is a criminal law judgment being made, with the attendant penalties that flow from that judgment. This is lost in Alexander's recklessness formula.

That brings us to advertence. Alexander writes:

[T] he justifiability of [the actor's] taking that risk is in turn a function of (1) the level of risk he perceives and (2) the reasons he has for taking that risk. Actors who impose risks on others that are not justified by their reasons are aptly characterized as "callous" or "indifferent."18

In other words, Alexander believes that a person is reckless even if she is unaware that the reasons for her conduct are outweighed by the risks she perceives (that is, she is unaware that her risk-taking is unjustifiable). For him, it is enough that the conduct-in light of the level of risk the actor perceives and the actor's reasons for taking the risk-is in fact unjustified.

15. Id. at cmt. 3, n.14 (emphasis added).

16. One way to explain the Code language is that "substantial risk" contains a normative feature: The risk must be substantial in light of the actor's purpose for taking the risk. Then, even a very small risk is "substantial" if the justification is virtually nonexistent. That is essentially the same as saying that risky conduct that is substantially unjustifiable constitutes recklessness.

17. Model Penal Code $\$ 2.02(2)$ (c) (emphasis added).

18. Alexander, supra note 2 , at 937 . 
In my view, this should not be the case, especially if recklessness implies callousness or indifference, as Alexander asserts.

Suppose that Alice consciously evaluates the risks inherent in her conduct, and determines that, based on her perceptions, there is a very small chance of causing harm $X$ to others. She considers her reasons for taking that risk and determines that it is a proper risk to take. But assume that Alice's ultimate calculations are faulty-she has undervalued the level of risk and/or overvalued her reasons for taking it. As a result, a jury concludes that she acted unjustifiably. She has made an honest effort to behave properly, but has erred. It is inaccurate, I submit, to characterize Alice as callous or indifferent to the rights of others, and yet Alexander would seemingly treat her as reckless.

In my view, what should justify a judgment of criminal recklessness is that the actor is aware that she is taking an unjustifiable risk or, at the very least, is aware that there is a significant likelihood that her intended conduct is unjustifiable, but she proceeds anyway, hoping that no harm occurs or not caring whether it does. This is where the substantiality requirement as I have characterized it-a substantially unjustifiable risk-serves a purpose missing in Alexander's model. When the actor's conduct falls a great distance from the line separating acceptable from unacceptable risk-taking, it is easy to conclude that, absent some excusing condition of the actor (such as mental illness), she must have realized that she was on the wrong side of the risk line or, at least, she must have been aware that she was taking a great risk of that error. Under these circumstances, the actor is properly stigmatized as reckless.

To conclude, I agree with Alexander that recklessness involves culpable belief- and desire-states, and that, properly characterized, recklessness involves an insufficient concern for the rights of others. I would define recklessness, however, in terms of risk-taking that is substantially or grossly unjustifiable, and I believe the law should require proof that the actor adverted to its very likely unjustifiability.

\section{II}

\section{PuRPose AND KNOWLEDGE}

Alexander advocates folding the concepts of purpose and knowledge into recklessness. ${ }^{19}$ He usefully demonstrates that the structure of the three states of mind are the same. They all contain belief-state and desire-state components which, at their foundation, demonstrate an insufficient concern for the rights of others. The three states of mind boil down to a single moral rule: "[C]hoose only those acts for which the risks to others' interests-as you estimate those risks-are sufficiently low to be outweighed by the

19. See id. at 931 . 
interests, to yourself and others, that you are attempting to advance (discounted by the probability of advancing those interests)."20

Alexander reasons that "purpose" not only has a desire-state (the conscious object of causing certain harm), but also a belief-state (the belief that the actor's conduct increases the likelihood, if only infinitesimally, of causing the desired harm). Moreover, like recklessness, there is a possibility of justification for the act. The only difference-which he finds to be of no substantive significance - is that with recklessness the nonjustifiability of the conduct is part of the definition of the term and must be proved by the State, whereas the actor has the burden of production (and, possibly, persuasion) regarding any justification for purposefully (or knowingly) ${ }^{21}$ causing harm. ${ }^{22}$

Knowledge involves a belief-state regarding the likelihood of causing harm (awareness of the virtual certainty of the harm). And, as with recklessness and purpose, knowledge contains a desire-state, a reason for acting, which could justify the conduct. Alexander argues that one benefit in collapsing knowledge into recklessness is that "it allows us to avoid the error of deeming all cases of knowledge to be more culpable than all cases of recklessness." 23 He makes a similar assertion about purpose-versusrecklessness. ${ }^{24}$

Alexander's analysis is insightful, but in response to his overall thesis, I find myself thinking, "Oh, yeah?" 25 My doubt arises because I hold to the epistemological view that the burden of persuasion should be on those who

20. Id. at 939.

21. See id. at 940 .

22. See id. at 942. At first glance, Alexander seems mistaken in his claim that there is no substantive difference, on the one hand, between the role of justification as a subelement in the definition of a mental state (recklessness) and, on the other hand, as a separate defense (knowledge or purpose). After all, if a risk-taker is justified, she has not acted recklessly, the mens rea element of an offense; but, if a person knowingly or purposely kills in self-defense, this justification does not negate the existence of the state of mind of knowledge or purpose. On closer inspection, however, the justification for an actor's conduct negates the actus reus-the social harm, if you will-of an offense in all of these cases. Just as with a justification defense, when an actor is justified in her risk-taking, the law is saying that society prefers (or, at least, tolerates) the risky conduct. See JosHuA DRESSLER, Understanding Criminal. Law $\S 16.03[\mathrm{~B}]$ (2d ed. 1995).

23. Alexander, supra note 2 at 940.

24. See id. at 944 .

25. There is also a "So what?" quality to my response. One supposed benefit of Alexander's proposal is that it avoids the common misclassification of wilful blindness-a "prototypical" case of recklessness-as "knowledge." See id. at 941-941. I assume this is a make-weight argumcnt. Other scholars agree with Alexander that wilful blindness is a lesser form of culpability than knowledge. See, e.g., Robin Charlow, Wilful Ignorance and Criminal Culpability, 70 TEx. L. REv. 1351, 1429 (1992) (wilful ignorance "is not as culpable as knowledge in all or most circumstances"); J. Edwards, The Criminal Degrees of Knowledge, 17 MOD. L. REv. 294, 303-05 (1954) (noting "a close affinity" between recklessness and wilful blindness); Ira P. Robbins, The Ostrich Instruction: Deliberate Ignorance as a Criminal Mens Rea, 81 J. CRIM. L. \& CRiminologY 191, 220-27 (1990) (wilful blindness is tantamount to recklessness). This only demonstrates that the law has misclassified the concept, and not that we must dispense with the knowledge/recklessness line. 
make claims that run counter to our common moral intuitions, and I do not think that Alexander has adequately made his case.

Am I right to put the burden on Alexander, based on our intuitions? Sandy Kadish has characterized as controversial the question of "whether we should strive to conform law to the imstinctive or to suppress it as far as we can im favor of the rational. ${ }^{266}$ According to Michael Moore, one of our foremost philosophers, we "should be interested in the common sense conception of [a condition of moral responsibility] itself only if we believe that conception to be accurate. ${ }^{27}$ Even if he is right in this regard, ${ }^{28}$ it is reasonable to start from the rebuttable proposition that the collective nontransitory intuitions of a community-assuming that they do not obviously conflict with other moral principles maintained by that community-are metaphysically correct. And here, I think, it is uncontroversial to assert that the common intuition (as evidenced by the common law and all penal codes) is that there are meaningful variations in culpability levels; it is counter-intuitive to believe that subjective fault can adequately be folded into a single concept of recklessness or insufficient concern.

Alexander defends a unitary system in considerable part by trying to demonstrate that the ordinary culpability hierarchy sometimes fails to coincide with our intuitions. He would have us contrast, as I would characterize them, Outraged Alexander (OA) with Madman Alexander (MA). ${ }^{29}$ OA knowingly inflicts severe bodily injury on $\mathrm{V}$ because $\mathrm{V}$ is about to accidentally destroy OA's entire life's work. In contrast, MA recklessly "impose[s] a slightly lower risk of the same harm ... to satisfy [his] urge to drive like a madman." ${ }^{30}$ Alexander argues that knowing OA is less culpable than reckless $\mathrm{MA}$, notwithstanding the traditional hierarchy that knowledge is more culpable than recklessness. We can avoid the "error" of our current system by folding the "higher" state of mind into the "lesser" recklessness concept.

But does this example prove his point? Let me begin with a third person, call him Error-ridden Alexander (EA). EA knowingly (or purposely) kills V in "self-defense" because he incorrectly believes that V intends to kill him. If EA has the misfortune of being prosecuted in, for example, New York, and if a jury concludes that EA was reckless or negligent in his belief, EA will lose his claim of self-defense and be convicted of knowing (or purposeful) murder. ${ }^{31}$ If our intuitions tell us that knowing (or

26. Kadish, supra note 7, at 394.

27. Michael S. Moore, The Metaphysics of Causal Intervention, 88 CAL1F. L. REv. 827 (2000); see also Paul H. Robinson, Some Doubts About Katz's and Other's Arguments by Hypotheticals, 88 CALIF. L. Rev. 813 (2000) (questioning the role of intuition in deontological argumentation) [Part III].

28. Cf. infra text at note 40 .

29. See Alexander, supra note 2, at 940 .

30. Id.

31. See, e.g., People v. Goetz, 497 N.E.2d 41, 50 (N.Y. 1986). 
purposeful) EA is less culpable than, for example, reckless MA, does this demonstrate that something is awry with our culpability system? No. It shows that New York has unwisely rejected the Model Penal Code approach of recogmizing partial defenses, and here EA should be entitled to a partial defense that would reduce his culpability to that of a negligently or recklessly mistaken wrongdoer. ${ }^{32}$

Look now at OA and MA. Most of us would probably agree that OA is the less culpable person, but it is not because the knowledge/recklessness line fails to work properly. It is because we sense that OA ought to be partially excused for his actions. One who observes another person jeopardize his entire life's work (no small product in Alexander's case) is apt to experience an emotional state that may seriously mitigate his offense. Indeed, if OA killed V in a Model Penal Code jurisdiction, he could make a plausible claim of extreme mental or emotional disturbance, ${ }^{33}$ which would reduce his offense to manslaughter, even as MA would probably be guilty of murder. ${ }^{34}$ The fact that OA has only wounded V, and that the emotional disturbance mitigation is not available, only shows that we should extend the partial excuse outside the homicide context or that something approaching perfect justice is unrealistic without devising an extraordinarily complex penal system. ${ }^{35}$

Alexander's example does not demonstrate that a reckless wrongdoer is sometimes more culpable than a knowing one. He has demonstrated instead that a reckless wrongdoer may be as culpable as or more culpable than a person who should be entitled to, but is not currently afforded, a partial defense in the law. Alexander needs to provide an example of a knowing (or purposeful) and fully unjustified and fully unexcused wrongdoer who is less culpable than a reckless (and, thus, fully unjustified) actor who causes the same harm.

But let's assume he can provide such an example. Then, my question (again respectfully) is, "So what?" Herbert Morris has observed that "we must feel the poverty of our concepts to capture neatly the variety of cases that the world throws up for our consideration. ${ }^{87}$ There are times when we may scratch our heads and concede that our culpability system is imperfect. But isn't the real question whether, in the vast majority of cases, our current culpability system works well? Concededly, if it often resulted in

32. See Model Penal Code $\$ 3.09$ (2) (1985).

33. See id. $\$ 210.3(1)(\mathrm{b})$.

34. See id. $\$ 210.2(1)(b)$ (citing recklessness as "manifesting an extreme indifference to the value of human life," which is the ultimate example of callousness).

35. See Kent Greenawalt, The Perplexing Borders of Justification and Excuse, 84 CoLum. L. REv. 1897, 1902-03 (1984) (suggesting that although scholarly efforts to systematically clarify the law can and should result in reform, "that illumination does not require embodiment of every subtle distinction in the criminal law itself").

36. For another "So what?" reaction, see supra note 25.

37. Herbert Morris, The Status of Rights, 92 ETHICs 40, 51 (1981). 
intuitively false culpability readings, we would need to decide whether, on the one hand, the hierarchy is faulty or incomplete,$^{38}$ or, on the other hand as Alexander contends, there is no true hierarchy to begin with.

Legislatures might prefer the clarity of a single bright line. A bright line is indefensible, however, unless it produces results closely approximating those which persons, left to their own devices, would reach on a case-by-case basis. ${ }^{39}$ The difficulty for Alexander's thesis is that "culpability" is not naturally an all-or-nothing concept. Juries regularly return verdicts for a lesser degree of an offense, not simply because they are given the option, but because they sense that not all culpable states of mind are morally alike. The "insufficient concern" umbrella, and the "single moral rule" that Alexander announces, although accurate, are too broad. The unified system fails to express the moral gradations of culpability that exist.

With offenses involving minor harm, and, thus where the stigma and ultimate punishment is fairly trivial, the distinctions between purpose, knowledge, and recklessness might not be important enough to draw. But the traditional lines remain worthwhile for dealing with serious (in other words, nearly all) offenses. I am reminded here of Sandy Kadish's warning to all of us, "that law has practical work to do and must govern people as they are, and ... it can not stray too far from deep rooted common perceptions without undermining public acceptance and compliance." ${ }^{20}$ And, in this case, Alexander falls well short, I think, of deinonstrating that our deeply rooted common perceptions are faulty.

38. Arguably, this is the case. For example, murder statutes typically divide intentional killings into still further degrees of culpability (deliberate premeditated intentional killings are worse than intentional killings lacking these features), whereas the Model Penal Code drafters, persuaded that such a distinction is false, abandoned it. See MODEL Penal CoDE $\$ 210.2(1)$.

39. See Wayne R. LaFave, The Fourth Amendment in an Imperfect World: On Drawing "Bright Lines" and "Good Faith", 43 U. PITT. L. REv. 307, 325-26 (1982).

40. Kadish, supra note 7, at 394. 
